\title{
Pengaruh Living Values Education Program (LVEP) terhadap Penanaman Anti-radikalisme Siswa SD dalam Pembelajaran Tematik
}

\author{
An-Nisa Apriani \\ Prodi PGSD Universitas Alma Ata Yogyakarta \\ e-mail: akunnisa@gmail.com \\ Intan Kurniasari Suwandi \\ Prodi PGSD Universitas Alma Ata Yogyakarta \\ e-mail: intan.djogdja@gmail.com
}

\begin{abstract}
Abstrak
Penelitian ini bertujuan untuk mengetahui pengaruh LVEP terhadap penanaman paham anti-radikalisme siswa SD kelas II dalam pembelajaran tematik. Jenis penelitian ini adalah quasi experiment dengan desain pretest-posttest control group design. Populasi dalam penelitian ini adalah seluruh siswa Kelas II SD yang terdiri dari lima kelas. Sampel terdiri dari dua kelas diambil dari kelima kelas tersebut untuk diberi perlakuan dengan menggunakan metode LVEP dan konvesional. Pemilihan sampel dilakukan secara acak dengan memperhatikan karakteristik siswa yang heterogen berdasarkan hasil wawancara dan observasi peneliti dalam pembelajaran tematik. Kelompok kontrol diberi perlakuan dengan pembelajaran konvensional, sedangkan kelompok eksperimen diberi perlakuan dengan menggunakan LVEP. Teknik pengumpulan data yang digunakan adalah observasi dan wawancara. Sedangkan teknik analisis data yang digunakan adalah uji-t dengan taraf signifikansi 0,05.

Hasil penelitian menunjukkan bahwa ada perbedaaan yang signifikan antara penanaman paham anti-radikalisme dengan LVEP dan pembelajaran konvensional. Perbedaaan tersebut terlihat di semua subkarakter anti-radikalisme yang mencakup nilai citizenship dengan hasil uji-t 0,065, nilai compassion dengan hasil uji-t 0,434, nilai courtesy dengan hasil uji-t 0,700, nilai fairness dengan hasil uji-t 0,504, nilai moderation dengan hasil uji t 1,000, nilai respect for other dengan hasil uji-t 0,826, nilai respect for creator dengan hasil uji-t 0,507, nilai self control dengan hasil uji-t 0,303, dan nilai tolerance dengan hasil uji t 0,676.
\end{abstract}

Kata Kunci: LVEP, anti-radikalisme, pembelajaran tematik

\begin{abstract}
This study aims to determine the effect of LVEP on the cultivation of anti-radicalism understanding of elementary school students in grade II in thematic learning. This type of research is a quasi experiment with pretest-posttest control group design. The population in this study were all students of Class II Elementary School consisting of five classes. The sample consisted of two classes and was treated using the LVEP and conventional methods. Random sample selection by considering the heterogeneous characteristics of students based on the results of interviews and observation of researchers in thematic learning. The control group was treated with conventional learning, while the experimental group was treated using LVEP. Data collection techniques used were observation and interviews. While the data analysis technique used is the t-test with a significance level of 0.05 .
\end{abstract}


The results showed that there was a significant difference between the cultivation of antiradicalism and LVEP and conventional learning. The difference is seen in all anti-radicalism sub-characters which include citizenship values with t-test results of 0.065 , compassion values with $t$-test results of 0.434 , courtesy values with $t$-test results of 0.700 , fairness values with $t$-test results of 0.504, moderation values with t-test results of 1.000 , respect for other values with $t$-test results of 0.826 , respect for creator values with t-test results of 0.507 , self control values with $t$-test results of 0.303 , and tolerance values with $t$-test results of 0.676 .

Keywords: LVEP, anti-radicalism, thematic learning

\section{PENDAHULUAN}

Pendidikan memiliki tujuan yang mulia, yaitu memanusiakan manusia, dalam arti menjadikan manusia lebih berperan sebagai manusia, lebih memahamai nilai-nilai dan hakikat sebagai manusia yang memahami nilainilai kemanusiaan yang jauh dari sikap dan tindakan kekerasan. Keberadaan manusia saat ini dipengaruhi oleh pendidikan sebelumnya dan keberadaan manusia masa depan dipengaruhi oleh pendidikan saat ini. Lingkungan pendidikan yang cukup berperan menanamkan nilai-nilai kehidupan bagi peserta didik adalah lembaga sekolah.

Sekolah sebagai kontrol sosial, berkepentingan memperbaiki kebiasaankebiasaan buruk siswa seperti mencela, kurang menghargai, tidak peduli, dan mengolok-ngolok. Dunia pendidikan saat ini tidak bisa terhindar dari fenomena kekerasan yang menjadikan tujuan pendidikan gagal tercapai. Berdasarkan catatan Harian Bali Post bahwa selama tahun 2010-2014 tercatat gerakan kekerasan yang terjadi di lembaga pendidikan sebanyak 21.689.7971 . Bentuk-bentuk kekerasan tersebut dialami oleh siswa ataupun guru. Priyanto menambahkan bahwa fenomena atau fakta kekerasan yang dapat dipahami sebagai bentuk radikalisme bisa dilihat dari kasus di SD yang terletak di Kelurahan Panggung, Kota Tegal. Dalam kasus tersebut terdapat 5 siswa yang

${ }^{1}$ Muhammad Saekan Muchith, Radikalisme dalam Dunia Pendidikan Jawa Tengah. ADDIN Vol.10, No.1, dapat diakses dari https://media.neliti.com/media/ publications/177465-IDradikalisme-dalam-duniapendidikan.pdf, 2016, hlm. 173-175. terlibat kekerasan dengan teman sekelasnya karena dilatar belakangi oleh ejekan yang membuat siswa tersebut tidak terima dan membalas perbuatan temannya ${ }^{2}$.

Masalah radikalisme yang sering muncul akhir-akhir ini adalah masalah kekerasan, tawuran antarsekolah, perkelahian antarpelajar, pembegalan sampai kepada pembunuhan antarpelajar yang bermula dari hal-hal yang tidak serius ${ }^{3}$. Gerakan radikalisme juga menyusup hingga ke lembaga-lembaga pendidikan, sehingga dunia pendidikan nasional perlu lebih perhatikan. Merebaknya paham radikalisme dapat berujung pada tindakan terorisme, di mana kalangan yang paling rawan untuk ditanami paham tersebut adalah anak-anak usia dini. Anak-anak usia dini, khususnya anak SD secara psikologis sudah selayaknya dibiarkan untuk bermain dan mencari teman sebanyakbanyaknya, tidak diindoktrinasi dan ditanamkan kebencian 4 .

Pelajar tingkat dasar perlu dibentengi dari ancaman paham kekerasan dan ideologi yang merusak generasi bangsa melalui pendidikan

${ }^{2}$ Mamdukh Adi Priyanto, Empat Siswa SD yang Diduga Terlibat Kekerasan Teman Sekelas Dipanggil Polisi dapat diakses dari http://jateng.tribunnews. com/2018/04/17/empat-siswa-sd-yang-diduga-terlibatkekerasan-teman-sekelas-dipanggil-polisi, 2018.

${ }^{3}$ Zulfani Sesmiarni, Membendung Radikalisme dalam Dunia Pendidikan melalui Pendekatan Brain Based Learning. Jurnal Studi Agama dan Pemikiran Islam, Vo. 9, No.2, 2015, hlm. 233-252.

${ }^{4}$ Gora Kunjana, Cegah Radikalisme dengan Pendidikan Karakter dapat diakses dari http:// id.beritasatu.com/home/mendikbud-cegah-radikalismedengan-pendidikan-karakter/176300, 2018. 
karakter bangsa yang diberikan secara berkesinambungan. Pendidikan karakter bangsa tersebut dapat berupa penguatan ideologi Pancasila serta pemahaman nilai-nilai agama yang benar ${ }^{5}$. Menteri Pendidikan dan Kebudayaan menjelaskan bahwa radikalisme di lingkungan sekolah dapat dicegah melalui Penguatan Pendidikan Karakter (PPK) yaitu aspek religius, nasionalis, integritas, gotong royong, dan mandiri di jenjang sekolah dasar. Melalui nilai-nilai utama yang ada dalam PPK tersebut, siswa belajar saling menghargai dan toleransi antarsesama, serta dapat memahami perbedaan ${ }^{6}$.

Berangkat dari temuan masalah tersebut, maka dapat digambarkan bahwa guru perlu melakukan inovasi model pembelajaran yang mendidik dan menanamkan nilai-nilai karakter anti-radikalisme. Salah satu model pembelajaran yang dapat diterapkan untuk mengembangkan pengetahuan, sikap dan tindakan antiradikalisme yaitu Living Values Education Program (LVEP). LVEP adalah program pendi-dikan yang membantu menyediakan kesempatan bagi anak-anak dan remaja untuk dapat menggali serta mengembangkan dua belas nilai-nilai universal: kedamaian, penghargaan, cinta, toleransi, kebahagiaan, tanggung jawab, kerjasama, kerendahan hati, kejujuran, kesederhanaan, kebebasan, dan persatuan ${ }^{7}$.

Penelitian ini bertujuan untuk mengetahui pengaruh $L V E P$ terhadap penanaman paham anti-radikalisme siswa SD kelas II pada pembelajaran tematik. Selain itu, penerapan model LVEP melalui pembelajaran tematik mampu meningkatkan nilai-nilai nasionalisme siswa kelas III SD Pujokusuman Yogyakarta.

${ }_{5}^{5}$ Adam Prawira, Pendidikan Karakter Mampu Bentengi Siswa dari Radikalisme dapat diakses dari https://nasional.sindonews.com/read/1260443/15/ pendidikan-karakter-mampu-bentengi-siswa-dariradikalisme-1511537561, 2018.

${ }^{6}$ Syarief Oebaidillah, Mendikbud Serukan Penguatan Pendidikan Karakter Cegah Radikalisme, dapat diakses dari http://mediaindonesia.com/read/ detail/163870-mendikbud-serukan-penguatanpendidikan-karakter-cegah-radikalisme.html, 2018.

${ }^{7}$ Diane Tillman, Living Values Activities for Children Ages 8-14. (Jakarta: Gramedia, 2004) hlm ix.
Living Values Education Program (LVEP) adalah program pendidikan nilai yang menawarkan berbagai pengalaman aktivitas nilai agar para siswa mampu menggali dan mengembangkan nilai-nilai kehidupan, yakni: kedamaian, penghargaan, cinta, toleransi, kebahagiaan, tanggung jawab, kerjasama, kerendahan hati, kejujuran, kesederhanaan, kebebasan, dan persatuan. Kegiatan pembelajaran yang dikemas dalam LVEP mencakup aktivitas refleksi dan imajinasi yang mendorong siswa untuk mengakses kreativitas dan bakatnya ${ }^{8}$.

Aktivitas komunikasi mengajarkan siswa untuk menerapkan keterampilan sosial kedamaian. Aktivitas artistik, lagu-lagu, dan tarian mengilhami siswa untuk mengekspresikan dirinya sambil mengalami nilai-nilai yang sedang difokuskan. Aktivitas pendidikan LVEP yang lain berupa permainan dan diskusi dengan tujuan memancing pikiran, menyenangkan, membantu siswa mengeksplorasi dampak dari berbagai sikap dan perilaku. Jadi, dapat disimpulkan bahwa nilai-nilai universal dalam LVEP mengajarkan penghargaan dan kehormatan untuk setiap orang dan semua orang. Siswa tidak sekedar mempelajari nilai-nilai tersebut tetapi mengalami dan menghayati nilainilai kehidupan dalam keseluruhan hidupnya.

Hasil kajian dari beberapa penelitian yang relevan menunjukkan bahwa LVEP yang diintegrasikan dalam pembelajaran tematik berpengaruh positif dalam menanamkan subkarakter nasionalisme dalam pembelajaran tematik: tanggung jawab, toleransi, kerja sama, persatuan, cinta, penghargaan, dan kedamaian'. Selain itu, integrasi dalam kegiatan pembelajaran dilakukan melalui integrasi nilai-nilai hidup menjadi materi, metode, media, sumber

${ }^{8}$ Diane Tillman, Living Values Activities for Children Ages 8-14. (Jakarta: Gramedia, 2004).

${ }^{9}$ An-Nisa Apriani, Indah Perdana Sari, \& Intan Kurniasari Suwandi, Pengaruh Living Values Education Program (LVEP) terhadap Penanaman Karakter Nasionalisme Siswa SD dalam Pembelajaran Tematik. Jurnal Taman Cendekia, Vol. 01, No. 02, 2017, hlm. 102-112. 
belajar dan penilaian. Selain itu, integrasi dalam kegiatan pembelajaran dan ekstrakurikuler mampu membangun berbagai nilai-nilai hidup, seperti disiplin, kooperatif, solidaritas, toleransi, peduli, kebersamaan, keberanian, tanggung jawab, kekompakan, kewirausahaan, kreativitas, kemandirian, kejujuran, keterampilan sosial dan kompetensi ${ }^{10}$.

LVEP memberikan efek yang signifikan pada perilaku dan sikap tertentu yang terkait dengan kecerdasan pribadi (intrapersonal dan interpersonal) pada siswa $\mathrm{SD}^{11}$. LVEP juga dapat dilakukan melalui pembelajaran sastra anak. LVEP dalam pembelajaran sastra anak mampu meningkatkan hasil belajar dan implementasi nilai-nilai budi pekerti anak (menaati ajaran agama, cinta dan kasih sayang, tanggung jawab, dan kerja sama ${ }^{12}$. Berdasarkan beberapa hasil penelitian tersebut dapat diketahui bahwa LVEP dapat membantu menanamkan paham antiradikalisme.

Radikalisme berarti (1) paham atau aliran yang radikal, (2) paham atau aliran yang menginginkan perubahan atau pembaharuan sosial dan politik dengan cara kekerasan atau drastis, (3) sikap ekstrem dalam aliran politik $^{13}$. Emna Laisa menambahkan bahwa radikalisme adalah suatu sikap atau pemikiran yang kemudian ditandai dalam empat hal

${ }^{10}$ Kokom Komalasari, Didin Saripudin \& Iim Siti Masyitoh, Living Values Education Model in Learning and Extracurricular Activities to Construct The Students' Character. Journal of Education and Practice, Vol. 5, No. 7, dapat diakses dari https://www.iiste.org/Journals/ index.php/JEP/article/view/11608, 2014, hlm. 166-174.

${ }^{11}$ Karma El Hassan \& Rula Kahil, The Effect of "Living Values: An Educational Program" on Behaviors and Attitudes of Elementary Students in a Private School in Lebanon. Early Childhood Education Journal. Vol. 33 No.2, dapat diakses dari https://eric.ed.gov/?id=EJ747025 2005, hlm. 81-90.

${ }^{12}$ Muh. Arafik, Living Values Education Program dalam pembelajaran sastra anak untuk meningkatkan nilai-nilai budi pekerti siswa SD. Tesis Magister, tidak diterbitkan, (Yogyakarta: Universitas Negeri Yogyakarta, 2010).

${ }^{13}$ Pusat Bahasa Depdiknas. Kamus Besar Bahasa Indonesia IV. (Jakarta: PT Gramedia Pustaka Utama, 2008). sekaligus menjadi karakteristik para kelompok radikal, yaitu: Pertama, sikap yang tidak toleran dan tidak mau menghargai apa yang menjadi pendapat dan keyakinan orang lain. Kedua, sikap fanatisme, sikap yang menganggap bahwasanya kelompoknyalah yang benar dan menyalahkan kelompok lain. Ketiga, sikap tertutup dan berusaha berbeda dengan kebiasaan khalayak umum. Keempat, kecenderungan menggunakan cara-cara kekerasan untuk mencapai tujuannya ${ }^{14}$.

Bentuk radikalisme dalam pendidikan ada yang berbentuk kekerasan, baik verbal maupun nonverbal. Muchith menjelaskan bahwa fenomena atau fakta kekerasan yang dapat dipahami sebagai bentuk radikalisme dapat dilihat dari beberapa kasus, diantaranya siswa di tempeleng guru dan guru olahraga menendang siswanya ${ }^{15}$. Selanjutnya, 5 siswa SD di Kelurahan Panggung, Tegal Timur terlibat kekerasan dengan teman sekelasnya yang dilatarbelakangi adanya ejekan yang membuat siswa tersebut tidak terima dan membalas perbuatan temannya ${ }^{16}$.

Bentuk radikalisme dalam pendidikan tidak semuanya berupa aksi kekerasan, tetapi juga dapat diwujudkan dalam bentuk ucapan dan sikap yang berpotensi melahirkan kekerasan yang tidak sesuai dengan norma-norma pendidikan ${ }^{17}$. Sikap yang berpotensi melahirkan

${ }^{14}$ Emna Laisa, Islam dan Radikalisme. Islamuna: Jurnal Studi Islam, Vol. 1, No. 1 dapat diakses dari http:// www.ejournal.stainpamekasan.ac.id/index.php/islamuna/ article/view/554, 2014, hlm. 1-18.

${ }^{15}$ Muhammad Saekan Muchith, Radikalisme dalam Dunia Pendidikan Jawa Tengah. ADDIN, Vol. 10, No. 1 dapat diakses dari https://media.neliti.com/media/ publications/177465-ID-radikalisme-dalam-duniapendidikan.pdf, 2016, hlm. 163-180.

${ }^{16}$ Mamdukh Adi Priyanto, Empat Siswa SD yang Diduga Terlibat Kekerasan Teman Sekelas Dipanggil Polisi dapat diakses dari http://jateng.tribunnews. com/2018/04/17/empat-siswa-sd-yang-diduga-terlibatkekerasan-teman-sekelas-dipanggil-polisi, 2018.

${ }^{17}$ Muhammad Saekan Muchith, Radikalisme dalam Dunia Pendidikan Jawa Tengah. ADDIN, Vol. 10, No.1,. Diakses dari https://media.neliti.com/media/ publications/177465-ID-radikalisme-dalam-duniapendidikan.pdf, 2016, hlm. 163-180. 
kekerasan tersebut berimplikasi kepada munculnya situasi dan kondisi sekolah yang tidak menyenangkan bagi siswa dalam belajar, menakutkan, mencemaskan, menegangkan, bahkan menyiksa lahir dan batin.

Untuk menangulangi terjadinya radikalisme dalam dunia pendidikan, maka diperlukan pendidikan anti-radikalisme. Pendidikan anti-radikalisme dapat dilakukan guru melalui proses pembelajaran, sehingga diharapkan dapat menciptakan masyarakat yang toleran dan cinta damai ${ }^{18}$. Alhairi menambahkan bahwa pendidikan anti-radikalisme di lingkungan sekolah dapat dilakukan dengan memasukkan nilai-nilai anti-radikalisme melalui proses pembelajaran dan penerapan nilai-nilai anti-radikalisme di lingkungan sekolah melalui empati dan kasih sayang ${ }^{19}$.

Guru kelas sebagai ujung tombak dalam pendidikan karakter harus memilih metode pembelajaran anti-radikalisme yang tepat dalam pembelajaran tematik guna mencegah tindakan kekerasan. Untuk mewujudkannya guru mengintegrasikan nilai-nilai pendidikan antiradikalisme dalam pembelajaran tematik. Nilainilai pendidikan anti-radikalisme ini diadopsi dari kurikulum karakter negara bagian Georgia: (1) Citizenship, yaitu kualitas pribadi seseorang terkait hak-hak dan kewajibannya sebagai warga negara; (2) Compassion, yaitu peduli terhadap penderitaan atau kesedihan orang lain serta mampu menanggapi perasaan dan kebutuhan mereka; (3) Courtesy, yaitu santun dan berbudi bahasa halus sebagai perwujudan rasa hormatnya terhadap orang lain; (4) Fairness, yaitu perilaku adil, bebas dari favoritisme maupun fanatisme golongan; (5) Moderation, yaitu menjauhi pandangan dan tindakan yang radikal dan ekstrem

${ }^{18}$ Novan Ardy Wiyani, Pendidikan Agama Islam Berbasis Anti Teroris di SMA. Jurnal Pendidikan Islam, Vol. 2, No. 1 dapat diakses dari https://www.researchgate. net/publication/271726032_Pendidikan_Agama_Islam Berbasis_Anti_Terorisme_di_SMA, 2013, hlm, 65-82.

${ }^{19}$ Älhairi, Pendidikan Anti Radikalisme: Ikhtiar Memangkas Gerakan Radikal. Jurnal Tarbawi, Vol. 14 No. 2 dapat di akses dari https://ejournal.unisnu.ac.id/ JPIT/ article/download/617/911, 2017, hlm. 109-122. yang tidak rasional; (6) Respect for the other, yaitu menghargai hak-hak dan kewajiban orang lain; (7) Respect for the creator, yaitu menghargai karunia yang diberikan oleh Tuhan Yang Maha Esa dan merasa berkewajiban untuk selalu menjalankan perintah-Nya dan menjauhi segala larangan-Nya; (8) Self control, yaitu mengendalikan diri melalui keterlibatan emosi dan tindakan seseorang; dan (9) Tolerance, yaitu menerima penyimpangan dari hal-hal yang dipercayai/praktik yang berbeda dengan yang dilakukan atau dapat menerima hal-hal yang berseberangan dengan yang telah menjadi kepercayaannya ${ }^{20}$.

Penanaman paham anti-radikalisme dalam dilakukan dalam pembelajaran tematik. Thematic approach is one of the teaching strategy that uses themes toward creating an active, interesting, and meaningful learning. Pembelajaran tematik mampu meningkatkan soft skill dan hard skill siswa. Selain itu, pengalaman belajar yang diperoleh siswa juga akan lebih utuh ${ }^{21}$. Penelitian ini menggunakan pendekatan tematik dan strategi LVEP untuk menanamkan karakter anti-radikalisme kepada kelas II siswa SD.

\section{METODE PENELITIAN}

Penelitian ini menggunakan quasiexperiment dengan pretest-posttest nonequivalent-group design, terdiri dari tahap persiapan, observasi awal, pemberian perlakuan, dan observasi akhir).

Penelitian ini dilaksanakan di Kelas II SD N Pujokusuman Yogyakarta pada semester genap Tahun Ajaran 2018/2019 yang terdiri dari

${ }^{20} \mathrm{Rd}$. Arif Mulyadi \& Lativa Novidasari, Peran Guru Pendidikan Agama Islam dalam Mencegah Radikalisme Islam di SMA Sejahtera 01 Depok. Safina, Vol. 2, No. 1 dapat diakses dari https://anzdoc.com/ peran-guru-pendidikan-agama-islam-dalam-mencegahradikalisme.html, 2017, hlm. 49-84.

${ }^{21}$ Min, Rashid \& Nazri, Teachers' understanding and practice towards thematic approach in teaching Integrated Living Skills (ILS) in Malaysia. International Journal of Humanities and Social Science, Vol. 2, No. 23 dapat diakses dari http://www.ijhssnet.com/journals/ Vol_2_No_23_December_2012/31.pdf, 2012, hlm. 273-281. 
4 rombongan belajar. Sampel dalam penelitian ini terdiri dari 2 kelas, yaitu kelas II A (kelompok kontrol) dan kelas II B (kelompok eksperimen). Kelompok eksperimen diberi perlakuan menggunakan $L V E P$, sedangkan kelompok kontrol tidak diberi perlakuan (konvensional). Sampel dipilih secara acak memperhatikan karakteristik siswa yang heterogen, berdasarkan hasil wawancara dan observasi. Wawancara digunakan untuk pengumpulan informasi awal penelitian, sedangkan observasi digunakan untuk pengamatan saat pretest (observasi awal) dan posttest (observasi akhir).

Analisa data pada penelitian ini terdiri dari dua tahap, yaitu analisis data tahap awal dan analisis data tahap akhir. Analisis data tahap awal dengan cara melakukan uji normalitas dan uji homogenitas. Uji normalitas terhadap data hasil observasi awal. Uji normalitas menggunakan program SPSS 17.0 for Windows dengan Kolmogorov-Smirnov. Data berdistribusi normal (Ha diterima) jika signifikansi $>$ dari tingkat alpha yang ditentukan yaitu $5 \%(0,05)$.

Uji homogenitas dilakukan untuk mengetahui apakah subyek penelitian berasal dari populasi yang homogen atau tidak. Varian variabel adalah sama (H diterima) jika taraf signifikansi $>$ dari tingkat alpha yang ditentukan yaitu 5\% $(0,05)$. Penelitian ini menggunakan uji Levene dengan bantuan program SPSS 17.0 for Windows.

Analisis tahap akhir penelitian menggunakan teknik analisis statistik inferensial untuk mengetahui apakah ada perbedaan rerata secara signifikan antara kelas eksperimen dan kelas kontrol dari skor hasil observasi awal dan observasi akhir. Hipotesisnya ialah

$\mathrm{H}_{0}$ : Tidak terdapat perbedaan signifikan rerata antara kelompok eksperimen dan kontrol.

$\mathrm{H}_{\mathrm{a}}$ : Terdapat perbedaan signifikan rerata antara kelompok eksperimen dan kontrol.

Pengambilan keputusan dan penarikan kesimpulan terhadap uji hipotesis menggunakan uji-t dilakukan pada taraf signifikansi 0,05. Kriterianya adalah

Jika nilai signifikansi $>0,05$, maka Ho diterima dan Ha ditolak
Jika nilai signifikansi $<0,05$, maka Ho ditolak dan Ha diterima

\section{HASIL DAN PEMBAHASAN}

Penelitian ini berlokasi di SD Negeri Pujokusuman. Bangunan sekolah berada di jalan kolonel Sugiyono No. 9 Yogyakarta. Dalam perkembangannya, SD tersebut berasal dari SD Pujokusuman 1, 2, 3, dan SD Percobaan yang dilebur menjadi satu (regrouping) dengan nama SD N Pujokusuman. SD N Pujokusuman memiliki karakteristik siswa yang heterogen baik agama, suku, budaya, sosial, dan ekonomi. Sekolah ini terletak di Kelurahan Keparakan, Kecamatan Mergangsan, Kota Yogyakarta, Daerah Istimewa Yogyakarta.

Kecamatan Mergangsan merupakan salah satu kecamatan yang berada di tengah kota Yogyakarta yang berkembang dengan pesat. Lokasi yang strategis memberikan pengaruh besar terhadap generasi muda, khususnya siswa SD dari berbagai aspek. Salah satu aspek yang menonjol adalah percepatan dan perkembangan teknologi. Percepatan dan perkembangan teknologi memberikan dampak terhadap pola pikir, pergaulan, dan kebiasaan anak-anak terutama siswa SD N Pujokusuman. Dampak positif dari perkembangan teknologi, siswa sangat mudah mengakses berbagai hal. Namun, kemudahan dalam mengakses informasi juga berdampak terhadap kecerdasan emosi dan sosial anak. Kecerdasan emosi dan sosial berperan penting dalam pembentukan karakter anak.

Peneliti berasumsi bahwa lokasi SD N Pujokusuman yang strategis dengan percepatan perkembangan teknologi menyebabkan siswa SD N Pujokusuman mudah mengalami pergesekan budaya. Pergesekan budaya antara budaya lokal dengan budaya asing dapat berpengaruh terhadap karakter anak yang rentan dengan sikap radikalisme. Sikap radikalisme ditunjukkan dengan sikap yang tidak mudah menerima perbedaan yang berseberangan dengan keyakinannya sehingga berdampak pada tindakan ekstrem yang menyakiti orang lain, baik ucapan maupun perbuatan. Anak SD 
merupakan sasaran utama dalam penanaman sikap radikalisme karena siswa SD suka meniru dan mudah dipengaruhi.

Berdasar data dari sekolah.data. kemdikbud.go.id, SD N Pujokusu-man mempunyai 26 rombongan belajar. Empat rombongan belajar diantaranya adalah kelas II SD N Pujokusuman sudah menerapkan Kurikulum 2013 sejak tahun 2013 dan saat ini semua kelas sudah menggunakan pendekatan pembelajaran tematik. Adapun kegiatan pembelajaran SD N Pujokusuman mulai tahun ajaran 2017/2018 diselenggarakan selama lima hari, yaitu Senin sampai dengan Jumat ${ }^{22}$.

Berdasarkan hasil sampling, maka penelitian dilaksanakan di kelas II A dan II B. Kelas II A berjumlah 30 siswa dan kelas II B berjumlah 30 siswa. Sumber belajar yang biasa digunakan di Kelas II A dan II B adalah buku tematik terpadu kurikulum 2013 edisi revisi 2017. Fasilitas yang tersedia di kelas untuk menunjang kegiatan pembelajaran ialah $L C D$ dan proyektor, papan tulis, dan rak untuk memajang hasil karya siswa.

Hasil wawancara terhadap guru kelas di kelas II A dan II B menunjukkan bahwa nilainilai anti-radikalisme cukup dipahami guru kelas, tetapi belum disisipkan dengan baik dalam proses pembelajaran tematik. Nilai-nilai anti-radikalisme terutama diajarkan kepada siswa melalui kegiatan upacara, menyanyikan lagu nasional, doa sebelum dan sesudah belajar, salam pagi, kegiatan literasi di perpustakaan, melaksanakan sholat dzuhur di sekolah, dan kegiatan Pramuka. Sedangkan nilai-nilai anti-radikalisme dalam proses pembelajaran tematik belum dilakukan secara khusus dengan model pembelajaran tertentu. Pembelajaran tematik yang dilakukan guru belum secara khusus memberikan penjelasan tentang paham radikalisme dan dampaknya. Guru kelas II masih dalam tahap penyisipan nilai-nilai antiradikalisme dalam materi pelajaran dengan

${ }^{22}$ Tim Dapodikbud, Sekolah Kita: SD Negeri Pujokusuman 1 dapat diakses dari http://sekolah.data. kemdikbud.go.id/index.php/chome/profil/f0b9b65c-2ef5e011-b104-5bd2eac64bca, 2019. pemberian contoh bagi siswa dan pengungkapan kalimat sederhana, tetapi belum maksimal.

Hasil observasi awal terhadap siswa SD kelas II A dan II B menunjukkan bahwa perilaku anak-anak cenderung mudah melakukan kekerasan dengan teman sebaya, pilih-pilih teman, mudah membalas perilaku kurang baik teman, sering mengucapkan kata-kata kasar, sering mengganggu teman, tidak menghargai guru saat mengajar, suka menyela, berbicara keras, dan sikap kurang bertanggung jawab terhadap perilaku kurang baik terhadap teman sebaya.

\section{Uji Prasyarat Analisis Data Uji Reliabilitas}

Tindakan pertama adalah melakukan uji reliabilitas terhadap hasil pengamatan perilaku tentang paham anti-radikalisme sebelum pretest untuk membuktikan bahwa pedoman observasi yang digunakan bersifat reliable. Uji reliabilitas pedoman observasi paham anti-radikalisme menggunakan rumus Borich dengan ketentuan bahwa nilai $\mathrm{R}$ lebih besar atau sama dengan $75 \%{ }^{23}$. Dengan demikian instrumen observasi bernilai naik dan layak digunakan jika memenuhi ketentuan.

Berdasarkan hasil ujicoba dapat dilihat bahwa instrumen pedoman observasi paham anti-radikalisme yang terdiri dari 32 indikator memperoleh nilai $\mathrm{R}$ lebih dari $75 \%$. Hal ini dibuktikan dengan penghitungan hasil observasi dari dua pengamat dengan rumus Borich. Dengan demikian instrumen pedoman obervasi paham anti-radikalisme bersifat reliabel.

Tindakan selanjutnya adalah mengumpulkan data pretest paham antiradikalisme. Data tentang paham antiradikalisme awal siswa diperoleh melalui pedoman observasi. Pretest pengamatan paham anti-radikalisme awal dilaksanakan pada bulan April 2019 pada kelompok eksperimen maupun kelompok kontrol.

${ }^{23}$ Borich, G. D., Observations Skills for Efective Teaching. (New York: Macmilan, 1994). 


\section{UJI NORMALITAS SEBARAN DATA}

Uji normalitas dilakukan dengan uji Shapiro-Wilk. Penggunaan uji normalitas ini dimaksudkan untuk mengetahui apakah populasi yang diselidiki berdistribusi normal atau tidak. Adapun kriteria pengujian yang digunakan untuk mengukur normalitas populasi dalam penelitian ini adalah Ho diterima apabila nilai Asymp. Sig. (2-tailed) $>$ dari tingkat alpha yang ditetapkan yaitu 0,05 .

Hasil uji normalitas paham antiradikalisme (pretest) pada kelompok kontrol dan eksperimen disajikan pada sebuah tabel. Berikut uji normalitas hasil pretest paham antiradikalisme kelompok kontrol.

Data bersifat normal jika nilai $\rho$ dari tabel dapat dilihat dari Asymp. Sig. (2-tailed) >0,05. Berdasarkan tabel di atas dapat dilihat bahwa nilai Asymp. Sig. (2-tailed) untuk kedua kelompok lebih besar dari $\alpha=0,05$ sehingga Ho diterima, yang berarti data hasil pretest-posttest pada kelompok kontrol dan eksperimen berdistribusi normal.

\section{Uji Homogenitas}

Uji homogenitas varians digunakan untuk mengetahui apakah sampel yang diambil dari populasi yang akan dikomparasikan memiliki varian yang sama atau tidak, menunjukkan perbedaan yang signifikan satu sama lain. Perhitungan uji homogenitas dilakukan dengan homogenitas Levene Statistic menggunakan fasilitas SPSS versi 17.00.

Adapun kriteria pengujian yang digunakan untuk menentukan homogenitas populasi dalam penelitian ini adalah Ho diterima apabila significancy ( $p$-value) $>$ dari tingkat alpha yang ditetapkan yaitu 0,05 dan Ho ditolak apabila nilai significancy $<$ dari alpha yang ditetapkan. Berikut hasil homogenitas dari data pretest dan posttest paham anti-radikalisme kelompok kontrol dan eksperimen.

Hasil uji homogenitas paham antiradikalisme (pretest-posttest) pada kelompok kontrol dan eksperimen disajikan pada Tabel 2.

Tabel 1. Uji Normalitas Hasil Pretest-Posttest Paham Anti-radikalisme Kelompok Kontrol dan Kelompok Eksperimen

Tests of Normality

\begin{tabular}{|c|c|c|c|c|c|c|}
\hline & \multirow{2}{*}{ Data } & \multirow{2}{*}{ Kelompok Statistic } & \multicolumn{3}{|c|}{ Shapiro-Wilk } & \multirow{2}{*}{ Kesimpulan } \\
\hline & & & $d f$ & Sig. & & \\
\hline \multirow{4}{*}{ Anti-radikalisme } & Pretest & Kontrol & ,949 & 30 & , 159 & Normal \\
\hline & Eksperimen & ,942 & 30 &, 103 & Normal & \multirow{3}{*}{ Normal } \\
\hline & Posttest & Kontrol & ,953 & 30 & ,203 & \\
\hline & Eksperimen & ,966 & 30 &, 431 & Normal & \\
\hline
\end{tabular}

Tabel 2. Hasil Uji Homogenitas Varian Data Pretest Paham Anti-radikalisme pada Kelompok Kontrol dan Kelompok Eksperimen

Test of Homogeneity of Variance

\begin{tabular}{|c|c|c|c|c|c|c|c|}
\hline & & Data & Levene Statistic & df1 & $d f 2$ & Sig. & Kesimpulan \\
\hline Anti- & Pretest & Based on Mean & 2,261 & 1 & 58 & ,138 & Homogen \\
\hline \multirow[t]{7}{*}{ radikalisme } & & Based on Median & 2,321 & 1 & 58 & ,133 & Homogen \\
\hline & & $\begin{array}{l}\text { Based on Median and with } \\
\text { adjusted df }\end{array}$ & 2,321 & 1 & 57,660 & ,133 & Homogen \\
\hline & & Based on trimmed mean & 2,213 & 1 & 58 & ,142 & Homogen \\
\hline & Posttest & Based on Mean &, 041 & 1 & 58 &, 840 & Homogen \\
\hline & & Based on Median & ,021 & 1 & 58 & ,887 & Homogen \\
\hline & & $\begin{array}{l}\text { Based on Median and with } \\
\text { adjusted df }\end{array}$ & ,021 & 1 & 56,656 &, 887 & Homogen \\
\hline & & Based on trimmed mean &, 035 & 1 & 58 & ,852 & Homogen \\
\hline
\end{tabular}


Dari hasil output SPSS didapatkan nilai probabilitas dengan uji Lavene test pada hasil pretest-posttest pada kelompok kontrol dan eksperimen sebesar 0,138. Dengan demikian karena nilai probabilitasnya lebih besar dari $\alpha=0,05$ sehingga Ho diterima, yang berarti varians data pada hasil pretest tersebut adalah homogen.

\section{Analisis Data Tahap Akhir}

Nilai-nilai anti-radikalisme mencakup sikap memahami hak dan kewajiban (citizenship), peduli terhadap penderitaan orang lain (compassion), santun dan berbudi halus (courtesy), adil (fairness), menjauhi tindakan yang ekstrem (moderation), menghargai hak dan kewajiban orang lain (respect for other), menjalankan perintahNya dan menjauhi larangan-Nya (respect for creator), mengendalikan emosi (self control), dan menerima hal yang berbeda (tolerance). Sedangkan nilai $L V E P$ terdiri dari nilai kedamaian, penghargaan, cinta, tanggung jawab, kebahagiaan, kerja sama, kejujuran, kerendahan hati, toleransi, kesederhanaan, dan persatuan. Dari berbagai nilai tersebut, ada keterkaitan antara nilai-nilai anti-radikalisme dengan nilai $L V E P$, yaitu nilai persatuan, toleransi, penghargaan, kedamaian, cinta, tanggung jawab, dan kerjasama. Keterkaitan antara LVEP dengan nilai anti-radikalisme berlandaskan pada $L V E P$ sebagai program pendidikan yang membantu menyediakan kesempatan bagi anak-anak dan remaja untuk dapat menggali serta mengembangkan nilai-nilai universal. Kesembilan nilai anti-radikalisme menjadi fokus dalam penelitian ini. Berikut ini hasil analisis uji-t paham anti-radikalisme beserta kesimpulannya.

\section{Nilai Citizenship}

Citizenship yaitu nilai yang mencerminkan kualitas seseorang yang melaksanakan hak dan kewajiban sebagai warga negara dengan baik. Nilai citizenship merupakan salah satu nilai anti-radikalisme yang menjadi fokus dalam penelitian. Penanaman nilai citizenship dalam pembelajaran konvensional maupun LVEP dikembangkan melalui aktivitas-aktivitas nilai. Berikut hasil uji-t nilai citizenship.

Tabel 3. Hasil Uji-t Nilai Citizenship

\begin{tabular}{cccc}
\hline Data & $\begin{array}{c}\text { Taraf } \\
\text { Signifikansi }\end{array}$ & $\begin{array}{c}\text { Asym Sig } \\
\text { (2-tailed) }\end{array}$ & Kesimpulan \\
\hline Pretest & 0,05 & 0,065 & Tidak ada beda \\
Posttest & 0,05 & 0,000 & Ada beda \\
\hline
\end{tabular}

Berdasarkan Tabel 3 di atas, hasil uji-t data menunjukkan bahwa P $0,000<0,05$ sehingga ditolak, artinya ada perbedaan antara rata-rata hasil pengamatan nilai citizenship kelompok kontrol dan kelompok eksperimen. Jadi, terdapat perbedaan nilai citizenship yang signifikan antara kelompok eksperimen yang menggunakan LVEP dan kelompok kontrol yang menggunakan konvensional.

\section{Nilai Compassion}

Compasion yaitu nilai yang mencerminkan sikap peduli terhadap kesedihan orang lain serta mampu menanggapi perasaan mereka. Nilai compassion merupakan salah satu nilai anti-radikalisme yang menjadi fokus dalam penelitian ini. Penanaman nilai compassion dalam pembelajaran konvensional maupun LVEP dikembangkan melalui aktivitas-aktivitas nilai. Berikut hasil uji-t nilai compassion.

Tabel 4. Hasil Uji-t Nilai Compassion

\begin{tabular}{cccc}
\hline Data & $\begin{array}{c}\text { Taraf } \\
\text { Signifikansi }\end{array}$ & $\begin{array}{c}\text { Asym Sig } \\
\text { (2-tailed) }\end{array}$ & Kesimpulan \\
\hline Pretest & 0,05 & 0,434 & Tidak ada beda \\
Posttest & 0,05 & 0,000 & Ada beda \\
\hline
\end{tabular}

Berdasarkan Tabel 4 di atas, hasil uji-t data menunjukkan bahwa P $0,000<0,05$ sehingga ditolak, artinya ada perbedaan antara rata-rata hasil pengamatan nilai compassion kelompok kontrol dan kelompok eksperimen. Jadi, terdapat perbedaan nilai compassion yang signifikan antara kelompok eksperimen yang menggunakan LVEP dan kelompok kontrol yang menggunakan konvensional. 


\section{Nilai Courtesy}

Courtesy merupakan salah satu nilai anti-radikalisme yang menjadi fokus dalam penelitian ini. Penanaman nilai courtesy dalam pembelajaran konvensional maupun LVEP dikembangkan melalui aktivitas-aktivitas nilai. Berikut hasil uji-t nilai courtesy.

Tabel 5. Hasil Uji-t Nilai Courtesy

\begin{tabular}{llll}
\hline \multirow{2}{*}{ Data } & $\begin{array}{c}\text { Taraf } \\
\text { Signifikansi }\end{array}$ & $\begin{array}{c}\text { Asym Sig } \\
\text { (2-tailed) }\end{array}$ & Kesimpulan \\
\hline Pretest & 0,05 & 0,700 & Tidak ada beda \\
Posttest & 0,05 & 0,000 & Ada beda \\
\hline
\end{tabular}

Berdasarkan Tabel 5 di atas, hasil uji-t data menunjukkan bahwa $\mathrm{P} 0,000<0,05$ sehingga ditolak, artinya ada perbedaan antara rata-rata hasil pengamatan nilai courtesy kelompok kontrol dan kelompok eksperimen. Jadi, terdapat perbedaan nilai courtesy yang signifikan antara kelompok eksperimen yang menggunakan $L V E P$ dan kelompok kontrol yang menggunakan konvensional.

\section{Nilai Fairness}

Fairness merupakan salah satu nilai anti-radikalisme yang menjadi fokus dalam penelitian ini. Nilaifairness dalam pembelajaran LVEP dikembangkan melalui aktivitas-aktivitas nilai. Berikut hasil uji-t nilai fairness.

Tabel 6. Hasil Uji-t Nilai Fairness

\begin{tabular}{cccc}
\hline Data & $\begin{array}{c}\text { Taraf } \\
\text { Signifikansi }\end{array}$ & $\begin{array}{c}\text { Asym Sig } \\
\text { (2-tailed) }\end{array}$ & Kesimpulan \\
\hline Pretest & 0,05 & 0,504 & Tidak ada beda \\
Posttest & 0,05 & 0,000 & Ada beda \\
\hline
\end{tabular}

Berdasarkan tabel di atas, hasil uji-t data menunjukkan bahwa $\mathrm{P} 0,000<0,05$ sehingga ditolak, artinya ada perbedaan antara rata-rata hasil pengamatan nilai fairness kelompok kontrol dan kelompok eksperimen. Jadi, terdapat perbedaan nilai fairness yang signifikan antara kelompok eksperimen yang menggunakan LVEP dan kelompok kontrol yang menggunakan konvensional.

\section{Nilai Moderation}

Moderation merupakan salah satu nilai anti-radikalisme yang menjadi fokus dalam penelitian ini. Nilai moderation dalam pembelajaran $L V E P$ dikembangkan melalui aktivitas-aktivitas nilai. Berikut hasil uji-t nilai moderation.

Tabel 7. Hasil Uji-t Nilai Moderation

\begin{tabular}{llll}
\hline \multirow{2}{*}{ Data } & $\begin{array}{c}\text { Taraf } \\
\text { Signifikansi }\end{array}$ & $\begin{array}{c}\text { Asym Sig } \\
(2-\text { tailed })\end{array}$ & Kesimpulan \\
\hline Pretest & 0,05 & 1,000 & Tidak ada beda \\
Posttest & 0,05 & 0,000 & Ada beda \\
\hline
\end{tabular}

Berdasarkan Tabel 7 di atas, hasil uji-t data menunjukkan bahwa P $0,000<0,05$ sehingga ditolak, artinya ada perbedaan antara rata-rata hasil pengamatan nilai moderation kelompok kontrol dan kelompok eksperimen. Jadi, terdapat perbedaan nilai moderation yang signifikan antara kelompok eksperimen yang menggunakan LVEP dan kelompok kontrol yang menggunakan konvensional.

\section{Nilai Respect for Other}

Respect for other merupakan salah satu nilai anti-radikalisme yang menjadi fokus dalam penelitian ini. Nilai respect for other dalam pembelajaran $L V E P$ dikembangkan melalui aktivitas-aktivitas nilai. Berikut hasil uji-t nilai respect for other.

Tabel 8. Hasil Uji-t Nilai Respect for Other

\begin{tabular}{cccc}
\hline Data & $\begin{array}{c}\text { Taraf } \\
\text { Signifikansi }\end{array}$ & $\begin{array}{c}\text { Asym Sig } \\
\text { (2-tailed) }\end{array}$ & Kesimpulan \\
\hline Pretest & 0,05 & 0,826 & Tidak ada beda \\
Posttest & 0,05 & 0,000 & Ada beda \\
\hline
\end{tabular}

Berdasarkan Tabel 8 di atas, hasil uji-t data menunjukkan bahwa P 0,000 < 0,05 sehingga ditolak, artinya ada perbedaan antara rata-rata hasil pengamatan nilai respect for other kelompok kontrol dan kelompok eksperimen. Jadi, terdapat perbedaan nilai respect for other yang signifikan antara kelompok eksperimen yang menggunakan $L V E P$ dan kelompok kontrol yang menggunakan konvensional. 


\section{Nilai Respect for Creator}

Respect for creator merupakan salah satu nilai anti-radikalisme yang menjadi fokus dalam penelitian ini. Nilai respect for creator dalam pembelajaran $L V E P$ dikembangkan melalui aktivitas-aktivitas nilai. Berikut hasil uji-t nilai respect for creator.

Tabel 9. Hasil Uji-t Nilai Respect for Creator

\begin{tabular}{cccc}
\hline Data & $\begin{array}{c}\text { Taraf } \\
\text { Signifikansi }\end{array}$ & $\begin{array}{c}\text { Asym Sig } \\
\text { (2-tailed) }\end{array}$ & Kesimpulan \\
\hline Pretest & 0,05 & 0,507 & Tidak ada beda \\
Posttest & 0,05 & 0,000 & Ada beda \\
\hline
\end{tabular}

Berdasarkan Tabel 9 di atas, hasil uji-t data menunjukkan bahwa $\mathrm{P} 0,000<0,05$ sehingga ditolak, artinya ada perbedaan antara rata-rata hasil pengamatan nilai respect for creator kelompok kontrol dan kelompok eksperimen. Jadi, terdapat perbedaan nilai respect for creator yang signifikan antara kelompok eksperimen yang menggunakan LVEP dan kelompok kontrol yang menggunakan konvensional.

\section{Nilai Self Control}

Self control yaitu salah satu nilai antiradikalisme yang menjadi fokus dalam penelitian ini. Nilai self control dalam pembelajaran LVEP dikembangkan melalui aktivitas-aktivitas nilai. Berikut hasil uji-t nilai self control.

Tabel 10. Hasil Uji-t Nilai Self Control

\begin{tabular}{llll}
\hline \multirow{2}{*}{ Data } & $\begin{array}{c}\text { Taraf } \\
\text { Signifikansi }\end{array}$ & $\begin{array}{c}\text { Asym Sig } \\
\text { (2-tailed) }\end{array}$ & Kesimpulan \\
\hline Pretest & 0,05 & 0,303 & Tidak ada beda \\
Posttest & 0,05 & 0,000 & Ada beda \\
\hline
\end{tabular}

Berdasarkan Tabel 10 di atas, hasil uji-t data menunjukkan bahwa P 0,000<0,05 sehingga ditolak, artinya ada perbedaan antara rata-rata hasil pengamatan nilai self control kelompok kontrol dan kelompok eksperimen. Jadi, terdapat perbedaan nilai self control yang signifikan antara kelompok eksperimen yang menggunakan LVEP dan kelompok kontrol yang menggunakan konvensional.

\section{Nilai Tolerance}

Tolerance merupakan salah satu nilai antiradikalisme yang menjadi fokus dalam penelitian ini. Nilai tolerance dalam pembelajaran LVEP dikembangkan melalui aktivitas-aktivitas nilai. Berikut hasil uji-t nilai tolerance.

Tabel 11. Hasil Uji-t Nilai Tolerance

\begin{tabular}{llll}
\hline \multirow{2}{*}{ Data } & $\begin{array}{c}\text { Taraf } \\
\text { Signifikansi }\end{array}$ & $\begin{array}{c}\text { Asym Sig } \\
\text { (2-tailed) }\end{array}$ & Kesimpulan \\
\hline Pretest & 0,05 & 0,676 & Tidak ada beda \\
Posttest & 0,05 & 0,000 & Ada beda \\
\hline
\end{tabular}

Berdasarkan Tabel 11 di atas, hasil uji-t data menunjukkan bahwa $\mathrm{P} 0,000<0,05$ sehingga ditolak, artinya ada perbedaan antara rata-rata hasil pengamatan nilai tolerance kelompok kontrol dan kelompok eksperimen. Jadi, terdapat perbedaan nilai tolerance yang signifikan antara kelompok eksperimen yang menggunakan LVEP dan kelompok kontrol yang menggunakan konvensional.

\section{KESIMPULAN}

Berdasarkan hasil analisis data diperoleh kesimpulan bahwa terdapat perbedaan paham anti-radikalisme yang signifikan antara kelompok eksperimen dengan pembelajaran LVEP dan kelompok kontrol dengan pembelajaran konvensional. Perbedaan tersebut terlihat disemua nilai anti-radikalisme yang diamati selama proses pembelajaran, yaitu citizenship, compassion, courtesy, fariness, moderation, respect for other, respect for creator, self control, dan tolerance. Proses penanaman paham anti-radikalisme melalui penelitian ini perlu dilanjutkan oleh guru kelas II SD N Pujokusuman pada khususnya dan guru SD N Pujokusuman pada umumnya. Pembelajaran dengan LVEP dapat digunakan oleh guru sebagai alternatif model pembelajaran guna menumbuhkan paham anti-radikalisme sebagai salah cara penguatan pendidikan karakter. Penanaman paham anti-radikalisme perlu ada dukungan dan kerjasama yang berkesinambungan antara guru, orang tua, 
dan masyarakat sekitar secara komitmen agar proses penanaman paham anti-radikalisme lebih efektif.

\section{DAFTAR PUSTAKA}

Adam Prawira, Pendidikan Karakter Mampu Bentengi Siswa dari Radikalisme, 2018. Diakses dari https://nasional.sindonews. $\mathrm{com} / \mathrm{read} / 1260443 / 15 /$ pendidikankarakter-mampu-bentengi-siswa-dariradikalisme-1511537561 pada tanggal 1 Agustus 2018.

Alhairi, Pendidikan Anti-radikalisme: Ikhtiar Memangkas Gerakan Radikal. Jurnal Tarbawi, No. 14, Vol. 2, 2017. Diakses dari https://ejournal.unisnu.ac.id/JPIT/ article/download/617/911 pada tanggal 20 Agustus 2018.

An-Nisa Apriani, Indah Perdana Sari, \& Intan Kurniasari Suwandi, Pengaruh Living Values Education Program (LVEP) terhadap Penanaman Karakter Nasionalisme Siswa SD dalam Pembelajaran Tematik. Jurnal Taman Cendekia, No. 01, Vol. 02, 2017.

Borich, G. D., Observations Skills for Effective Teaching. (New York: Macmilan, 1994).

Diane Tillman, Living Values Activities for Children Ages 8-14, (Jakarta: Gramedia, 2004).

Emna Laisa, Islam dan Radikalisme. Islamuna: Jurnal Studi Islam, No. 1, Vol. 1, 2014. Diakses dari http://www. ejournal.stainpamekasan.ac.id/index.php/ islamuna/article/view/554, pada tanggal 19 Agustus 2018.

Karma El Hassan \& Rula Kahil, The Effect of "Living Values: An Educational Program" on Behaviors and Attitudes of Elementary Students in a Private School in Lebanon. Early Childhood Education Journal. Vol. 33, No.2, 2005. Diakses dari https://eric. ed.gov/?id=EJ747025 pada tanggal 16 Agustus 2018.

Kokom Komalasari, Didin Saripudin \& Iim Siti Masyitoh, Living Values Education Model in Learning and Extracurricular Activities to
Construct The Students' Character. Journal of Education and Practice, Vol. 5, No. 7, 2014. Diakses dari https://www.iiste.org/ Journals/index.php/JEP/article/view/11608 pada tanggal 7 Agustus 2018.

Mamdukh Adi Priyanto, Empat Siswa SD yang Diduga Terlibat Kekerasan Teman Sekelas Dipanggil Polisi, 2018. Diakses dari http://jateng.tribunnews.com/2018/04/17/ empat-siswa-sd-yang-diduga-terlibatkekerasan-teman-sekelas-dipanggil-polisi pada tanggal 3 Agustus 2018.

Min, Rashid \& Nazri, Teachers' understanding and practice towards thematic approach in teaching Integrated Living Skills (ILS) in Malaysia. International Journal of Humanities and Social Science, No. 2, Vol. 23, 2012. Diakses dari http://www. ijhssnet.com/journals/Vol_2_No_23 December_2012/31.pdf pada tanggal 20 Juli 2018.

Muh. Arafik, Living Values Education Program dalam pembelajaran sastra anak untuk meningkatkan nilai-nilai budi pekerti siswa SD. Tesis Magister, tidak diterbitkan, (Yogyakarta: Universitas Negeri Yogyakarta, 2010).

Muhammad Saekan Muchith, Radikalisme dalam Dunia Pendidikan Jawa Tengah. ADDIN, No. 10, Vol. 1, 2016. Diakses dari https://media.neliti.com/media/ publications/177465-ID-radikalismedalam-dunia-pendidikan.pdf pada tanggal 1 Agustus 2018.

Pusat Bahasa Depdiknas. Kamus Besar Bahasa Indonesia IV. (Jakarta: PT Gramedia Pustaka Utama, 2008).

Rd. Arif Mulyadi \& Lativa Novidasari, Peran Guru Pendidikan Agama Islam dalam Mencegah Radikalisme Islam di SMA Sejahtera 01 Depok. Safina, No. 2, Vol. 1, 2017. Diakses dari https://anzdoc.com/ peran-guru-pendidikan-agama-islamdalam-mencegah-radikalisme.html pada tanggal 20 Juli 2018.

Syarief Oebaidillah, Mendikbud Serukan Penguatan Pendidikan Karakter Cegah 
Radikalisme, 2018. Diakses dari http:// mediaindonesia.com/read/detail/163870mendikbud-serukan-penguatanpendidikan-karakter-cegah-radikalisme. html pada tanggal 1 Agustus 2018.

Tim Dapodikbud, Sekolah Kita: SD Negeri Pujokusuman 1, 2019. Diakses dari http:// sekolah.data.kemdikbud.go.id/index.php/ chome/profil/f0b9b65c-2ef5-e011-b1045bd2eac64bca pada tanggal 2 Agustus 2019.

Zulfani Sesmiarni, Membendung Radikalisme dalam Dunia Pendidikan melalui Pendekatan Brain Based Learning. Jurnal Studi Agama dan Pemikiran Islam, No. 9, Vol.2, 2015.

Gora Kunjana, Cegah Radikalisme dengan Pendidikan Karakter dapat diakses dari http://id.beritasatu.com/home/ mendikbud-cegah-radikalisme-denganpendidikan-karakter/176300, 2018.

Muhammad Saekan Muchith, Radikalisme dalam Dunia Pendidikan Jawa Tengah. ADDIN No.10, Vol.1, 2016. Diakses dari https://media.neliti.com/media/ publications/177465-IDradikalismedalam-dunia-pendidikan.pdf pada tanggal 1 Agustus 2018.

Novan Ardy Wiyani, Pendidikan Agama Islam Berbasis Anti Teroris di SMA. Jurnal Pendidikan Islam, No. 2, Vol. 1, 2013. Diakses dari https://www. researchgate.net/publication/271726032 Pendidikan_Agama_Islam_Berbasis Anti_Terorisme_di_SMA pada tanggal 20 Juli 2018. 